\title{
Az idősödő társadalom pénzügyi kontextusa
}

\author{
Kuti Mónika \\ Pécsi Tudományegyetem
}

\begin{abstract}
A TANULMÁNY CÉLJA
A tanulmány célja, hogy az idősödő társadalom hatására megjelenő komplex pénzügyi folyamatokat áttekintse. Az idősödő társadalom jelentős mértékben átformálja a pénzügyek világát, hatással van a kockázati attitüdre, a kockázat-megtérülés viszonyrendszereire, a megtakarítási hajlandóságra, beruházásokra, produktivitásra, fogyasztásra, az eszközárakra, a pénzügyi közvetítőrendszerre, valamint a fiskális egyensúlyra és monetáris politikára egyaránt.
\end{abstract}

\begin{abstract}
ALKALMAZOTT MÓDSZERTAN
Alkalmazott módszertant tekintve a cikk elsősorban szakirodalom-kutatás, melynek célja, hogy rendszerezze a nemzetközi kutatások fontosabb irányait és kutatási kérdéseit.
\end{abstract}

\section{LEGFONTOSABB EREDMÉNYEK}

A cikk legfontosabb eredménye, hogy rámutat arra, hogy az idősödő társadalom költségvetési egyensúlyproblémákat okoz, a monetáris transzmisszó hatékonyságán módosít, a kockázatmentes befektetések iránti keresletet fokozza, a bankszektorban a bankbetét-állomány növekedéséhez vezet, a nyugdíjbiztosítási rendszert kihívások elé állítja. Az egészségügyi kockázatok miatt az idősek háztartási vagyonportfóliójában az egészségügyi kiadások mint negatív tőke egyre jelentősebb mértékben jelentkeznek, a családon belüli transzferek jelentőségét fokozzák az alacsonyabb jövedelemmel rendelkező társadalmi rétegekben.

\section{GYAKORLATI JAVASLATOK}

A kutatási eredmények alapján megfogalmazható gyarkolati javaslatok közé tartozik, hogy a pénzügyi közvetítő rendszer számára fontosak olyan metrikák kialakítása, melyek számszerüsítik a fenti generációs kockázatokat.

Kulcsszavak: idősödő társadalom, kockázat, megtakarítások, nyugdíjrendszer

Köszönetnyilvánitás: Az „EFOP-3.6.1-16-2016-00004. Átfogó fejlesztések a Pécsi Tudományegyetemen az intelligens szakosodás megvalósítása érdekében" címủ pályázat támogatásával. (Időskori döntéshozatal projektelem, 11. téma)

DOI: 10.15170/MM.2021.55.KSZ.02.05 


\section{BEVEZETÉS INTRODUCTION}

A populáció idősödése a világon több országban okoz számos kihívást a nemzetgazdaság különböző szintjein, beleértve a nyugdíjrendszer finanszírozását, a jövedelemtranszferek kihívásait, a kockázatmentes megtakarítások iránti emelkedő keresletet, és részvénypiaci anomáliákat. A jelenlegi és a jövőbeli generációk gazdasági biztonsága vezető közpolitikai aspektus ott, ahol a demográfia az idősebbek felé tolódik. Az idősödő társadalom okozta problémák kezelésének mozgásterét behatárolja legtöbb országban a költségvetési korlát. A társadalombiztosítási rendszerekre egzisztenciális veszélyt jelent globálisan az idősödő társadalom, a nyugdíjbiztosítási rendszerek alulfinanszírozottsága szintén közismert probléma.

Egyértelmű összefüggés, hogy az idősödő társadalomban a várható élettartam növekedése magyarázatul szolgál a lassuló GDP növekedésre, a kamatlábak csökkenésére és a produktivitás romlására (Cooley \& Henriksen 2017). Ugyanakkor megfogalmazható az is, hogy az idősödő társadalmakban a szenior munkaerő aktivizálása hatékony lehet a gazdasági növekedés visszaesésének elkerülésében (Lee 2019). Az idősödő társadalom Európában a gazdasági lassuláshoz több csatornán keresztül járul hozzá: részben a hosszabb, nyugdíjban eltöltött életkor, részben a csökkenő gazdasági aktivitási időszak jelentik a direkt hatásokat; a költségvetési egyensúly fenntartásához kivetett adóemelés pedig az indirekt összefüggéseket (Cooley et al. 2019). Az idősödő társadalom a közép-jövedelem országcsapdájának eshetőségét jelenti a munkások per fogyasztók fenntarthatatlan arányai miatt, vagyis az idősödés gátja annak, hogy egyes ázsiai országok a magas jövedelmű országkategóriába át tudjanak lépni (Ha \& Lee 2019). A munkaerőpiaci változások a középjövedelműek iránti kereslet kiüresedését hozzák, mely probléma számos országot érint.

A vagyon generációs eloszlása is központi kérdés az idősödő társadalmakban. Az idősebb korosztályok gazdaságilag biztonságosabb helyzetben vannak, mint a fiatalabbak az USÁ-ban nettó vagyon szempontjából, sőt a társadalombiztosítási hálók is nagyobb védelmet nyújtanak számukra. Megfigyelhető, hogy a szegénységi ráta 65 év után emelkedik, továbbá jobban ki vannak téve katasztrofális egészségügyi költségeknek mozgáskorlátozottság vagy demencia miatt. A költséges egészségügyi sokkok kimeríthetik a háztartási megtakarításokat, függetlenül attól, hogy fiatal vagy idősebb korosztályokról van szó. Az egész- ségügyi és idős ápolással kapcsolatos kiadások megfelelő biztosítás nélkül - komoly terhet rónak a családokra. A pénzügyi sérülékenységnek olyan társadalmi hatásai is lehetnek, hogy az életciklus végén azok tapasztalhatnak pénzügyi kirekesztést idős korukban, akik jövedelem nélkül maradnak, alacsony a pénzügyi kultúrájuk, kognitív és fizikai romlás jeleivel küzdenek és alacsony a digitális kompetenciaszintjük (GPFI \& OECD 2019).

A családon belüli transzferek növelhetik vagy kimeríthetik az idősebbek gazdasági biztonságát. A házasság egyfajta biztosításként fogható fel arra az esetre, ha valamelyik házastárs elvesztené a munkáját vagy egészségét. A házasságban élők nagyobb gazdasági biztonsággal rendelkeznek az egyedül élőkhöz képest kedvezőtlen élethelyzetek kezelése szempontjából. A finanszírozandó hoszszabb várható életkor és az eszközökön elérhető alacsonyabb megtérülések további sérülékenységi pontokat jelentenek számukra. A nyugdíj előtt állók vagyonmérlegei alapján látszik, hogy ők kevésbé vannak felkészülve a nyugdíjas évekre, mint elödjeik. A késő középkorú férfiak nagyobb pénzügyi nehézségeknek lesznek kitéve a korábbi generációkhoz képest, míg a hölgyeknél ezek a tendenciák nem látszanak ilyen mértékben (Brown et al. 2019).

\section{A BIZTONSÁGOS ESZKÖZÖK SZÜKÖSSÉGE ÉS A,ZÉRÓ KOC- KÁZATÚ TÁRSADALOM" THE LACK OF RISKFREE AS- SETS AND THE ,ZERO RISK SOCIETY"}

Az értékpapírtartás szempontjából számos kockázat fogalmazható meg az idősödő társadalmakban a generáció befektetési időtávja, kockázatkerülése és a befektetések megtérülésével kapcsolatos elvárásai kapcsán. Az alacsony hozamkörnyezet nem megfelelő megtérülést nyújt a nyugdíj célú megtakarításokon; az alacsony előtakarékoskodási hajlandóság, a nyugdíjkorhatár feszültségei, a hagyományos családi támogatás rendszereinek gyengülése és az időskori elszegényedés problematikus területek. Az idősebb korosztály alacsony kockázat-vállalási hajlandósága hatással van arra az eszközallokációs trendre, hogy a nemzetgazdaság portfolió-rebalanszírozása szempontjából mekkora mozgástér marad kockázatos és kockázatmentes eszközök közötti választás során a nagyobb megtérülést, de nagyobb kockázatot jelentő befektetési és beruházási alternatívák rovására. Két irányt érdemes figyelembe venni ezen folyamatok megértéséhez. Egyrészt az 
emelkedő várható élettartam fokozza az óvatossági megtakarítások iránti igényt, annak érdekében, hogy az értékőrzés funkciót betöltő biztonságos formákban tudhassák az időskorúak vagyonelemeik egy részét, ami hatalmas kötelezettségállományként jelenik meg a bankoknál és intézményi befektetőknél, mint például a nyugdíjalapoknál vagy a biztosítóknál. Másrészt az idősödő populáció emeli a biztonságos eszközök iránti aggregált keresletet, teszi ezt oly módon, hogy döntései során hogyan súlyoz a korfüggő vagy háztartási életciklusra épülö, kockázatos és kockázatmentes eszközök között. Következésképpen, az idősödő társadalmakban megemelkedett a növekedési és vagyon célú biztonságos eszközök iránti kereslet, ami ezen eszközök szükösségéhez vezet. A biztonságos eszközök hiánya hozzájárul a finanszírozási kockázatok felhalmozódásához azáltal, hogy egyben a privát hitelnövekedést is hajtja. A kutatások is alátámasztják ezt, hiszen pozitív a kapcsolat a biztonságos eszközök hiánya és a pénzügyi rendszer hitelexpanziós aggregált kockázata között, sőt a biztonságos eszközök hiánya a pénzügyi krízisek legfőbb előre jelzője (Kim 2019).

Ahogy a népesség közelít a 65 éveskorhoz, egyre jobban szembesül azzal, hogy életciklusuk alatt kevesebbet tudtak megtakarítani, kevésbé váltak jogosultak nyugdíjra és társadalombiztosításra, kevesebb ingatlanvagyonuk lett, mely folyamatok direkt módon vezetnek az időskori elszegényedéshez (Rasmussen 2018). Az idősödő lakosság magasabb megtakarítási aránya a bankbetétek lokális emelkedését eredményezheti, ami hitelezési standardok lazulásához, magasabb hitel per jövedelem arányokhoz, kevesebb elutasított hitelkérelemhez, és nagyobb arányú nem teljesítő hitelállományhoz vezet - a kockázatkeresés a kompetitív piacokon, illetve fiókhálózat nélküli területeken a bankok esetében nő (Doerr et al. 2020). Összességében, tehát az idősödő társadalom a pénzügyi rendszer stabilitását rendíti meg.

Az idősödő társadalom az alacsony kockázatvállalás felé tolja el a beruházási és befektetési hajlandóságot, torzulást okozva a kockázat-megtérülés összefüggéseire építő pénzügyi modellek alapdimenziói mentén. A Swiss Financial Institute egyik tanulmányában nevesítik, hogy egy, kontroll-megszállottsággal és „kockázattalanítással” jellemezhető ún. „zéró kockázatú kultúrában” (zero-risk culture) élünk, mely az idősödő társadalmak és a vagyonnövekedés következtében beálló kockázatkerülés, a lehetőségekhez korlátozottan hozzáférő polgárok egyenlőtlenségének növekedése, a kontroll illúziót teremtö technológia, a közösségi média vezérelt másolás és nyájszellem, valamint a szél- sőségek és a túlreagálás különféle formáihoz vezet (Sornette \& Cauwels 2020).

$\mathrm{Az}$ értékpapírpiacokon a generációs eloszlás is számos kockázat forrása. Az Amerikai Egyesült Államokban 2019-ben a befektetési alapok tulajdonosi szerkezetében az 1946 elött született generációk a teljes állomány 58\%-át tették ki az ICI Fact Book (2019) adatai alapján, melyből jól látható az idősebb generációk erőteljes jelenléte a pénzügyi piacok ezen részén is. A kérdés az, hogy az időskorúak az idő előrehaladtával mit kezdenek értékpapír-portfóliójukkal, eladják-e azt napi likviditás-pótlás céljából vagy ráhagyományozzák az utódokra? Vannak olyan vélekedések, hogy a „baby boomerek" részvény-likvidációja részvénypiaci összeomláshoz vezet, melyet intergenerációs modellek futtatásával is alátámasztottak (Poterba 2001, 2005, Abel 2001, Brooks 2003).

A pandémia a nyugdíj előtt álló korosztályok számára olyan helyzetet teremtett, hogy a pénzügyi portfólióikban bekövetkezett jelentős értékveszteség miatt meg kell fontolniuk az alkalmazkodás lehetőségét. Az USÁ-ban az 55-60 évesek között végzett felmérés szerint 44\%-uk halasztja el a nyugdíjba vonulást, $18 \%$-uk további 5 , vagy még több évet kíván dolgozni (SimplyWise 2020). A felmérés szerint az idősebb munkavállalók viszont a pandémia miatt hamarabb veszik inkább igénybe a nyugdíjszolgáltatásokat, illetve ahol lehetőségük van, a részleges nyugdíjazást választják, miközben még dolgoznak.

A világjárvány miatt a nyugdíjmegtakarítási programok a világon mindenhol komoly kihívások elé néznek, a kockázatmegosztás új modelljeit hozhatják (Mitchell 2020). A szerző hangsúlyozza, hogy a pénzügyi kultúra növelése, a megtakarítási programok ösztönzése, a befektetések intelligensebb kezelése, a hosszabb életkor jobb menedzselése, a munkáltatók leválasztása a nyugdíjmegtakarításokról, az egészségbiztosításokról, és a pénzügyi tanácsadásról olyan szempontok, amiket érdemes megfontolnia hosszabb távon a döntéshozóknak. 


\section{IDŐSÖDŐ TÁRSADALOM HATÁ- SA A TŐKEKERESLETRE ÉS A REÁLESZKÖZ-ÁRAKRA THE IMPACT OF AGEING SOCI- ETY ON CAPITAL DEMAND AND REAL ASSET PRICES}

A demográfiai elmozdulások meghatározzák a tőkekeresletet és -kínálatot a várható élettartam csatornáján, valamint a kor mint kohorsz jellegü népességi eloszlásokon keresztül. A várható élettartamban bekövetkezö változások nemcsak az egyének életciklus-megtakarításaikat befolyásolja, hanem a munkaerőkínálatát is. A megtakarítások mértéke és a munkaerőkínálat mennyiségileg fontos önbiztosítási csatornáknak számítanak a nemzetgazdaságok számára, hogy kezeljék a megnövekedő élettartam-kockázatokat és nyugdíjkifizetéseket (He et al. 2019).

A kohorsz-eloszlásban bekövetkező változások viszont az egyéni döntések aggregátumát határozzák meg. A bérdinamikák és a reálkamatlábak változnak a tőkével és munkával kapcsolatos kereslet és kínálat mozgásával. A háztartások életkora meghatározza a megtakarítási hajlandóságot, ami - a megtakarítási-beruházási egyensúlytalanságon keresztül - hat a nemzetgazdasági folyófizetési egyenlegre, sőt kimutatható, hogy a demográfiai trendek meghatározták a G7 országok közötti hosszú távú tőkemozgást, a megtakarítási többletet magasabb időskorúak arányával rendelkezö országok hajlamosak exportálni és folyófizetési többletet generálni (Feroli 2003). Ráadásul, idősödő populációval rendelkező országok - a gyorsan változó munkakörnyezetre adott kognitív adaptációs nehézségek okán - komparatív előnyüket lassan elveszítik olyan iparágakban, amelyek erősen támaszkodnak a munkaerő gyakori kompetencia-alkalmazkodására (Gu \& Stoyanov 2017).

Az ingatlan az egyik legáltalánosabb befektetési eszköz a társadalomban, különösen a közép- és felsőbb társadalmi osztályokban; fiatalabb korosztályok számára vagyonakkumulációs szándék húzódik meg az ingatlanvásárlás mögött, míg idősebbeknél nyugdíjcélú ingatlaneladás jelenik meg. Párizs és Amszterdam adatait felhasználva a XIX. század végétől a XX. század elejéig a szabadpiac idején, beleértve a bérleti díjakat, az ingatlan árakat és a bérlet per ingatlanár arányokat, kutatók kimutatták, hogy 5 éves születési arányban bekövetkező egy százalékpontos növekedés hatással van a keresletre, 25 évvel később 5\%-os növekedést eredményez az ingatlan árakban, de 60-65 évvel később ugyanennyivel csökkenti azt, miközben a bérleti dijakra csupán kis mértékben hat a demográfiai struktúra, ellenben a bérleti díj per ingatlanár arányokra, azaz a bérleti hozamokra eröteljesen hat 60 évvel később (Francke \& Korevaar 2020). Következésképp megfogalmazható, hogy gyorsan idösödő társadalmakban az ingatlanárak csökkennek, bevándorlók hullámai azonban kompenzálhatják ezeket a negatív trendeket.

Az életciklus modell kapcsán megfogalmazódott, hogy az emberek úgy alakítják ki a megtakarítási és befektetési eszközportfólióikat, hogy a nyugdíjukat tudják fedezni az eszközök lebontásával. Jellemzően, az idősödéssel az eszközök lehívása fokozódik, ahogy a bérjövedelmek elapadnak nyugdíjazás után és helyette a nyugdíj „,fogyasztása" indul el. Racionális döntésnek tünik, hogy időskorban az emberek a nettó ingatlanvagyonuktól is megválnak, hogy finanszírozni tudják szükségleteiket. Ezzel szemben a kutatások azt mutatták $\mathrm{ki}$, hogy az ingatlanvagyonukat a háztartások nem hívták le, és két fôs háztartásban nettó vagyonnövekedést figyeltek meg (Poterba et al. 2011). Az ingatlan-tulajdonossági ráta magas marad 70 éves korig, azután hirtelen csökkeni kezd; amikor idősek elköltöznek a lakásból, az 55-64 évesek inkább kisebb ingatlanra váltanak, a 65-74 évesek inkább nagyobbra, a 75 felettiek pedig kisebbre cserélik korábbi ingatlanaikat (Megbolugbe et al. 1997). Időskorúan nem szívesen költöznek el az ingatlanukból, sőt akik mégis költözésre szorulnak, azok sem csökkentik ingatlan-vagyonukat; vagyis nem likvidálják ingatlanjaikat az általános fogyasztási szükségleteik megtámogatása céljából, kivéve, ha valamilyen lesújtó sokk éri őket a házastárs elvesztésével vagy betegség miatt (Venti \& Wise 2000). Következésképpen, az időskorúak az ingatlanra inkább mint akkumulált vagyonra tekintenek. E trendek hívták életre az ingatlan-alapú nyugdijkiegészítés mint biztosítási terméket.

A Világbank a „reverz” jelzáloghitelezésben (reverse mortgage) látta sokáig annak a jólétnövelő és fogyasztás-simítást lehetővé tevő pénzügyi instrumentumnak a létjogosultságát, ami a nyugdíjjövedelmek kiegészítéseként egyfajta biztosításként funkcionálhatna az ingatlanban gazdag, de pénzeszközökben szegény csoportoknak, s egyben hozzájárulna a pénzügyi sokkoknak való ellenállóképesség fokozásához is, valamint az egyén-specifikus - várható életkor, egészség, társ elhalálozása, egészségügyi kiadások területeivel összefüggő - kockázatok csökkentéséhez (Knaack et al. 2020). A szerzők rámutatnak a kockázatokra is: a fennálló hitelállomány egyenlege, a kontraszelekció, az erkölcsi kockázat, a biztosításkötés aktuáriusi modellek 
hiányára visszavezethető magas költségei, a csalásokkal övezett pénzügyi termék hírnévkockázata, a kockázati állományegyesítés opcióinak hiánya és a szabályozói ösztönzők tisztázatlanságai jelentik azokat a főbb okokat, amik miatt a pénzügyi szolgáltatók többsége kiszállt ebből a piacból.

Problémát okoz az ún. ,szük keretalkotás” idősödő társadalmakban, vagyis az, hogy az embereket a biztosítási díjakat kezdeti, drága kiadásként látják, szemben a távoli és bizonytalan biztosítási kifizetésekkel (Gottlieb \& Olivia 2015). Pedig pont az egészségbiztosítások, a nyugdíjbiztosítások és a vagyonsokkok elleni pénzügyi védelem lehetnek azok a módozatok, melyek megvédhetik az időskorúakat a kedvezőtlen kimenetekkel szemben (Mitchell 2017).

A magas jövedelmủ országokban a felnőtt lakosság 46\%-a takarékoskodik a nyugdíjas évekre, míg az alacsony és közép jövedelmủ országokban ez az arány 16\% (WBG 2017). Olyan országokban, ahol magas a lakosság ingatlantartása, miközben alacsony a nyugdíjcélú megtakarítási képessége vonzó lehet egy ilyen nyugdijkiegészítést nyújtó termék. Az említett költségek feltörekvő országokban még magasabbak lehetnek, mint a fejlett régiókban. A hitelösszeget az ingatlan ára, a hitelfelvelő kora, a hitelfelvétel költségei és az eszközárban várható változások volatilitása határozza meg, továbbá aktuáriusi modellek szükségesek a hitel futamideje és a várható élettartam illesztéséhez.

\section{AZ IDŐSÖDŐ TÁRSADALOM HATÁSA AZ INFLÁCIÓRA THE IMPACT OF AGEING SOCI- ETY ON INFLATION}

Jelentős szakirodalom halmozódott fel arról, hogy az idősödés hogyan hat egyes makroökonómiai tényezőkre. Míg a gazdasági növekedés és a fiskális egyensúlyra kifejtett hatások tekintetében viszonylagos összhang uralkodik a szakirodalomban, ugyanez nem mondható el az infláció kapcsán. A kérdés tehát, hogy az idősödés inflációs és dezinflációs hatást fejt-e ki továbbra is számos kutatót foglalkoztat. Megfigyelhetö, ahogy a társadalmon belül az idősek aránya emelkedik, úgy fokozódik az igény az általuk preferált árstabilitás iránt, melynek célja, hogy megvédjék bankbetétjeik és fix hozamú értékpapírjaik értékét.

Demográfiai változások esetén, az egyének életciklus döntései hatással vannak a fogyasztási keresletre és a pénztartásra, ezeken keresztül pedig az inflációra. A populációméretben bekövetkező változások hajtják leginkább az idősödő társadalom és az infláció közötti kapcsolatot, míg a populáció-struktúra kevésbé, másképp fogalmazva az idősödő társadalmak inkább deflációs hatásnak vannak kitéve, míg a fiatal országok szembesülnek inflációs nyomással (Härtl \& Leite 2018).

Az idősödő társadalom lefelé irányuló nyomást gyakorol az inflációra, s közben magasabb az infláció volatilitása, egyben az őszhajú társadalmakban a monetáris politika kevésbé hatékony (Baksa \& Munkácsi 2019). Az alacsony inflációs környezethez a „baby boom” generáció munkaaktivitása, a globalizáció és az automatizáció is hozzájárul (Mojon \& Ragot 2020).

\section{A VÁLLALATI SZFÉRA ÉS A VÁLLALKOZÓISÁG AZ IDŐSÖ- DŐ TÁRSADALOMBAN CORPORATE SECTOR AND ENT- REPRENEURSHIP IN AGEING SOCIETY}

Az idősödő társadalom a vállalkozói kultúrára és a vállalati szférára is hatással van. Megfigyelték, hogy azon családokban, ahol magasabb az idősebbek aránya, illetve ahol magasabb az idősek függőségi rátája, alacsonyabb a vállalkozói hajlandóság Kínában, vagyis az idősödő társadalom vállalkozóiságra tett negatív hatását figyelembe kell venni az üzleti világ élénkítése során (Liao \& Fan 2020).

Az idősödő generációk nemcsak a kis- és középvállalatoknál okoznak generációváltási kihívásokat, hanem a nagy cégeknél is. Az inter-generációs vagyontranszfer kapcsán visszaélések történhetnek, melynek kezelése nemzetgazdasági érdek idősödő társadalmakban.

A vállalatok milyen kapcsolatban vannak az idősödő társadalommal, idősebb személyek hogyan hatnak a vállalati döntéshozatalra? Ezen kérdések mentén Ortar (2020) készített átfogó, rendszerező jellegủ szakirodalomkutatást, melyben a közpolitikai szabályozói aspektusokat, az öszhajúakban lévő piaci potenciált és az egy életen át ívelő tanulást vizsgálja meg fókuszpontokként. 65 év fölötti vállalati igazgatósági tagok egyre nagyobb aránya figyelhető meg az Egyesült Államokban amiatt is, hogy a kötelező nyugdíjazástól egyre több vállalat tekint el független igazgatók esetén. Az idősebb igazgatók - energia és mentális kapacitás híján már nem követik a cég legfrissebb fejlesztéseit, az aktuális iparáig trendeket megfelelő intenzitással, illetve nem veszik időben észre a technológiai innovációk által létrehozott új növekedési lehetöségeket. Idősebb igazgatóknak kevesebb lehetősége van 
a munkaerőpiacon, nagyobb az ösztönzöttségük a csöndes élet élvezetére és arra, hogy bevételeik maximalizására törekedjenek.

Nagy vállalatoknál a 65 év feletti igazgatósági tagok viselkedése és döntései új vetületeket nyitnak a vállalati értékteremtés és a vállalatkormányzás standard dimenzióihoz képest. Az idősebb független igazgatósági tagok ritkábban vesznek részt az igazgatósági üléseken, kevésbé valószínű, hogy kulcs igazgatósági bizottságokat vezetnek, az éves választásokkor kevesebb részvényesi támogatást kapnak, jelenlétükben erősebb a vállalati birodalomépítés, kisebb részvényesi értéket teremtő akvizíciók jönnek létre, engedékenyebbek az alulteljesítő vezérigazgatókkal szemben, és gyengébb a pénzügyi beszámolók minősége szolgálati idejük alatt (Masulis et al. 2020). A szerzők hozzáteszik, hogy kulcsdöntésekben azonban a tapasztalataik és erőforrásaik értékes tanácsadói hozzáadott értékké válnak.

Iparági visszaesések a CEO-k szolgálati ideje alatt csökkentik a várható élettartalmat, gépi tanulás módszertannal a CEO-k fotóit elemezve azt találták, hogy a Nagy Világgazdasági válság idején a vezetök egy évvel néztek ki idősebbnek a saját koruknál az elkövetkező évtizedekben (Borgshuelte et al. 2020). Az idősödő munkavállalói réteg kezelése szintén számos kihívást, valamint produktivitási és müködési kockázatot jelent a vállalat számára, melyet humánpolitika szintjén kezelnie kell munkakörülmények és javadalmazás szempontjából. A vállalatok részmunkaidős, munkába való visszatérést, és más, egyedi elbíráláson alapuló technikákkal reagálnak az idősödő munkavállalói hullámra (Clark et al. 2019).

\section{AUTOMATIZÁCIÓ-ORIENTÁLT BERUHÁZÁSOK IDŐSÖDŐ TÁR- SADALMAKBAN INVESTMENTS INTO AUTOMA- TION IN AGEING SOCIETIES}

Az elmúlt évek érdekes kutatási iránya a robotizáció és automatizáció kérdésköre az idősödő társadalmakban. A fejlett országokban tapasztalható idősödő társadalom a gazdasági növekedés lassulásának egyik faktora. Ezzel párhuzamosan azonban a kedvezőtlen demográfiai trendek egyben együtt járnak olyan technológiai válaszokkal, melyek a humántényezőt kiváltó folyamatok katalizátorai, a robotizáció és automatizáció motiválói.

A populációban bekövetkező változások és a robotikába irányuló invesztíció közötti kapcsola- tok vizsgálata során kutatók arra mutattak rá, hogy miközben a robotok a középkorú munkaerőt helyettesítik, a nagyobb idősebb per középkorú aránnyal rendelkező társadalmakban erőteljesebb beruházási aktivitás jelent meg a robot technológiák és az automatizáció adoptálása irányában, melynek következtében a produktivitás emelkedhet a munkaerőarány csökkenésével az időskorúak számának emelkedése ellenére (Acemoglu \& Restrepo 2018). A robotizáció tehát a kieső munkaerőt kiegészítő erőforrástényezővé válik az idősödő társadalmakban.

\section{KÖVETKEZTETÉSEK CONCLUSIONS}

Az idősödő társadalom hatásai interdiszciplináris alapon vizsgálthatók igazán, mely túlmutat jelen tanulmány keretein. A pénzügyi világot jelentős nyomás alá helyezi az őszhajú populáció népesedése. Az idősödő társadalom a hozamkörnyezetet az alacsony megtérülés felé torzítja, csökkenti a tőkeköltséget, beruházás-allokációs hatékonytalanságokhoz vezet, fokozza a többi generáció kockázatkereső befektetési aktivitását, az inflációra nyomást fejt ki, csökkenti az ingatlanárakat kereslet alapon, hatástalanná teszi a monetáris transzmissió hagyományos csatornáit, valamint nem szokványos módon felgyorsítja a robotizációba és a digitális transzformációba irányuló beruházásokat. A pandémia tovább kihívásokat okoz számos fronton. A felsorolásból is érzékelhető, hogy a pénzügyi folyamatokat - a maguk komplexitásában - szinten minden területen átformálja. 


\section{HIVATKOZÁSOK REFERENCES}

Abel, A. B. (2001), "Will Bequests Attenuate the Predicted Meltdown in Stock Prices when Baby Boomers Retire?", The Review of Economics and Statistics, 83(4): 589-595 DOI: $10.3386 /$ w8131

Acemoglu, D., Restrepo, P. (2018), "Demographics and Automation", MIT Department of Economics, Working Paper No. 18-05 DOI: 10.2139 ssrn. 3138621

Baksa, D., Munkacsi, Zs. (2019), "More Gray, More Volatile? Aging and (Optimal) Monetary Policy", IMF Working Paper, No. 19/198, DOI: 10.5089/9781513509082.001

Borgschulte, M., Guenzel, M., Liu, C., Malmendier, U. (2020), "CEO Stress, Aging, and Death", CEPR Discussion Paper, No. DP14933, Available at SSRN: https://ssrn.com/abstract=3638037 (Utolsó letöltés: 2021.01.15.)

Brooks, R. (2003), "Population Ageing and Global Capital Flows in a Parallel Universe", IMF Staff Papers, 50(2), DOI: 10.5089/9781451857023.001

Brown, J., Dynan, K. E., Figinski, T. (2019), “The Risk of Financial Hardship in Retirement: A Cohort Analysis", Wharton Pension Research Council Working Paper, No. 2019-10, DOI: $10.2139 / \mathrm{ssrn} .3540470$

Clark, R. L., Nyce, S., Ritter, B., Shoven, J. B. (2019), "Employer Concerns and Responses to an Aging Workforce", NBER Working Paper, No. w25572, DOI: 10.3386/w25572

Cooley, T. F., Henriksen, E., Nusbaum, C. (2019), "Demographic Obstacles to European Growth", NYU Stern School of Business, DOI: 10.2139/ ssrn.3356824

Cooley, T. F., Henriksen, E. (2017), "The Demographic Deficit", SSRN, DOI: 10.2139/ ssrn.3067781

Doerr, S., Kabas, G., Ongena, S. R. G. (2020), "Population Aging and Bank Risk-Taking", Swiss Finance Institute Research Paper, No. 20-62, DOI: $10.2139 / \mathrm{ssrn} .3430184$

Feroli, M. (2003), "Capital flows among the G-7 nations: A demographic perspective", FEDS Working Paper, 2003-54, Federal Reserve Board, DOI: 10.2139/ssrn.481643

Francke, M., Korevaar, M. (2020), "Baby Booms and Asset Booms: Demographic Change and the Housing Market", SSRN, DOI: 10.2139/ ssrn. 3368036
Gottlieb, D., Olivia S. M. (2015), "Narrow Framing and Long-Term Care Insurance", NBER Working Paper, 21048, DOI: 10.3386/w21048

GPFI \& OECD, (2019), G20 Fukuoka Policy Priorities on Aging and Financial Inclusion.

Gu, K., Stoyanov, A. (2017), "Skills, Population Aging, and the Pattern of Trade", SSRN, DOI: $10.2139 /$ ssrn.3115922

Ha, J., Lee, S. (2018), "Population Aging and the Possibility of a Middle-Income Trap in Asia", ADBI Working Paper, 536, DOI: 10.2139/ ssrn. 3188471

Härtl, K., Leite, D. N. (2018), "The Aging-Inflation Puzzle: On the Interplay between Aging, Inflation and Pension Systems", MEA Discussion Paper, No. 06-2018, DOI: 10.2139/ ssrn. 3291310

He, Hui, Ning, L., Zhu, D. (2019), “The Impact of Rapid Aging and Pension Reform on Savings and the Labor Supply", IMF Working Paper, No. 19/61, DOI: 10.5089/9781498302890.001

ICI Fact Book (2019), https://www.icifactbook.org/ ch7/20 fb_ch7 (Utolsó letöltés: 2021.01.15.)

Kim, S. (2019), "The Nexus of Safe Asset Shortage, Credit Growth and Financial Instability", SSRN, https://ssrn.com/abstract=3405204 (Utolsó letöltés: 2021.01.15.)

Knaack, P. Miller, M., Stewart, F. (2020), "Reverse Mortgages, Financial Inclusion, and Economic Development: Potential Benefit and Risks", World Bank Policy Research Working Paper, No. 9134, DOI: 10.1596/1813-9450-9134

Lee, J. (2019), "Population Aging and Economic Growth: Impact and Policy Implications", KDI Policy Forum, No. 273(2019-02), DOI: 10.3386/w16705

Liao, H., Fan, G. (2020), "Aging and Family Entrepreneurship: Evidence from Urban China", SSRN, 1 August 2020, DOI: 10.2139/ ssrn. 3703442

Masulis, R. W., Wang, C., Xie, F., Zhang, S (2020), "Directors: Older and Wiser, or Too Old to Govern?", European Corporate Governance Institute (ECGI) - Finance Working Paper, No. 584/2018, DOI: $10.2139 /$ ssrn.3284874

Megbolugbe, I., Sa-Aadu, J., Shilling, J. (1997), "Oh, Yes, the Elderly Will Reduce Housing Equity under the Right Circumstances", Journal of Housing Research, 8(1), 53-74

Mitchell, O. S. (2017), "Enhancing Risk Management for an Aging World", Wharton Pension Research Council Working Paper, No. 2017-18, DOI: $10.2139 / \mathrm{ssrn} .3670962$

Mitchell, O. S. (2020), "Building Better Retirement Systems in the Wake of the Global Pandemic", 
CFS Working Paper, No. 644, DOI: 10.2139/ ssrn.3731009

Mojon, B., Ragot, X. (2020), "Can an Ageing Workforce Explain Low Inflation?", BIS Paper, No. 111g, Available at SSRN: https://ssrn.com/ abstract $=3576027$ (Utolsó letöltés: 2021.01.15.)

Ortar, L. (2020), "Time for Corporate Gerontology: A Systematic Literature Review", SSRN, 23 Sep 2020, DOI: $10.2139 /$ ssrn.3670158

Poterba, J. M. (2001), "Demographic Structure and Asset Returns", The Review of Economics and Statistics, 83(4), 565-584 DOI: $0.1162 / 003465301753237650$

Poterba, J. M. (2005), "The Impact of Population Aging on Financial Markets", In Gordon H. Sellor, Jr., ed. "Global Demographic Change: Economic Impact and Policy Challenges". Kansas City: Federal Reserve Bank of Kansas City, 163-216 DOI: $10.3386 / w 10851$

Poterba, J. M., Venti, S., Wise, D. (2011), “The
Composition and Drawdown of Wealth in Retirement", Journal of Economic Perspectives, 25(4), 95-117 DOI: 10.2469/dig.v42.n2.39

Rasmussen, D. W. (2018), "Poverty in Retirement: The Long-Term Impact of Rising Economic Inequality"? SSRN, 4 May 2018, DOI: 10.2139/ ssrn. 3172935

SimplyWise (2020), New Study: 4 in 10 Americans at Risk of Delaying Retirement, https://www. simplywise.com/blog/study-4-in-10-may-delay-retirement/ (Utolsó letöltés: 2021.01.15.)

Sornette, D., Cauwels, P. (2020), "Trapped in the "zero-risk" society and how to break free", Swiss Finance Institute Research Paper, No. 20-78, DOI: 10.2139/ssrn.3684550

Venti, S. F., Wise, D. A. (2000), "Aging and Housing Equity", NBER Working Paper, No. 7882, DOI: $10.3386 /$ w7882

WBG (2017), Global Findex. https://globalfindex. worldbank.org/ (Utolsó letöltés: 2021.01.15.)

\section{Financial Context behind Ageing Society}

\section{THE AIM OF THE PAPER}

The aim of the study is to highlight the complex financial processes, how ageing society transforms the financial world, how it affects risk attitude, risk-return trade offs, the willingness to save, investments, productivity, consumption, asset prices, financial intermediation, fiscal balance and monetary policy.

\section{METHODOLOGY}

The methodology of the study is an in-depth literature survey to reveal the dominant research trends and questions.

\section{MOST IMPORTANT RESULTS}

The most important findings of the article is that ageing leads to fiscal imbalances, it modifies the efficiency of monetary transmission, it increases the demand for riskfree investments, including the growth of bank deposits in the banking sector, and it puts a pressure on the pension systems. Owing to health risks, the health related expanses appear as negative capital in the household portfolios of the elderly, and the transfers within the families are more prevelant in low income cohorts of the society.

\section{RECOMMENDATIONS}

Based on the research findings, the recommendation is as follows: it is advisable for the financial intermediaries to develop metrics to quantify the generational risks.

Keywords: ageing society, risk, savings, pension system 